\title{
Inocybe sectio Calosporae in NW Europe
}

\author{
JUKKA VAURAS
}

\begin{abstract}
VAURAS, J. 1989: Inocybe sectio Calosporae in NW Europe. - Karstenia 28:79-86.
Two species in the section Calosporae are recognized in NW Europe: Inocybe calospora Quélet and I. multicoronata A.H. Smith. The species are described, illustrated and mapped, and their ecology and taxonomic relationships are discussed. I. multicoronata is reported as new to Europe, where it is known from one locality in Finland.
\end{abstract}

Jukka Vauras, Department of Biology, University of Turku, SF-20500 Turku, Finland

The section Calosporae J. Lange sensu Horak in the genus Inocybe is characterized by subglobose to ellipsoid spores, covered with conical, bifurcate, crestlike or saddle-shaped projections. The carpophores are slender with a usually squamulose or squarrose pileus. Some species have a cortina or veil. The stipe varies from totally or apically pruinose to fibrillose to even squamulose. Most species are tropical (Horak 1979, 1981).

The only species in the Holarctic region accepted in this study are I. calospora Quélet and I. multicoronata A.H. Smith. The latter, hitherto reported only from Nova Scotia, Canada (Smith 1939, Grund \& Stuntz 1968), was recently found in Finland.

As $I$. multicoronata clearly resembles $I$. calospora macroscopically, the material of I. calospora was checked in the followirig herbaria: C, GB, H, IB, KUO, LD, O, OULU, S, THR, TUR, UPS. No specimens of $I$. multicoronata were found, and no specimens deposited under that name were received on loan from these herbaria.

The descriptions of the species are based on Nordic material. The colours of fresh specimens were compared with Cailleux, Code des Couleurs des Sols. The microscopical characters of material in $10 \% \mathrm{NH}_{4} \mathrm{OH}$ solution were drawn with a Leitz drawing tube. The spore dimensions were obtained by measuring 20 spores from each collection studied.

\section{Key to species}

1 Spores with blunt, conical-cylindrical spines; pleurocystidia less than $60 \mu \mathrm{m}$ in length ................... I. calospora

- Spores with compound warts, crowned with smaller obtuse projections; pleurocystidia longer than $60 \mu \mathrm{m}$ I. multicoronata

\section{Inocybe calospora Quelét}

- Figs. 1-5

Inocybe calospora Quelét in Bres., Fungi Trid. 1:19. 1882. Astrosporina calospora (Quelét) Rea, British Basidiomyc.: 211. 1922. - Inocybella calospora (Quelét) Zerov in Zerov \& Peresipkin, Viznachnik Gribiv Ukraini 5, Basidiomycetes (2): 347. 1979.

Inocybe gaillardii Gillet, Rev. Mycol. 5:31. 1883. 1888

Inocybe subfulva Peck, Ann. Rep. N.Y. State Mus. 41:66.

Inocybe echinocarpa Ellis \& Everh., J. Mycol. 5:26. 1889.

Inocybe rigidipes Peck, Ann. Rep. N.Y. State Mus. 51: 289. 1898. 1913.

Selected illustrations. Heim, Genre Inocybe: pl. 33, fig. 5. 1931. - Lange, J., Flora Agar. Dan. 3: pl. 115, figs. C \& Cl. 1938. - Stangl, Zeitschr. Pilzk. 42: pl. 2. 1976. Alessio, Iconogr. Mycol. 29, Suppl. 3: pl. 76. 1980. Moser \& Jülich, Farbatlas Basidiomyc.: pl. Inocybe 23. 1985. — Leisner \& Kalamees, Eesti narmasnutid: pl. 34. 1987.

Pileus $0.3-2.5 \mathrm{~cm}$ in diam, $2-8 \mathrm{~mm}$ high, conical to hemispherical when young, then conico-convex, mostly distinctly umbonate; surface felted, often with small fibrillose squamules, recurved especially around disc, usually not splitting but sometimes rimulose to disc; mostly dark brown $(50 / \mathrm{T}, 51 / \mathrm{T})$, sometimes reddish brown $(37 / \mathrm{T})$, disc concolorous or darker, rarely yellow-brown $(67 / \mathrm{N})$. Lamellae up to $4 \mathrm{~mm}$ broad, slightly adnexed, whitish to pale grey when young, then grey-brown $(70 / \mathrm{N})$, then brown $(47 / R, 75 / P)$; edge fimbriate, concolorous or paler. Cortina not seen. Stipe $1.5-5 \mathrm{~cm}$ long, $1-3 \mathrm{~mm}$ wide, equal to somewhat clavate to subbulbous (base up to $5 \mathrm{~mm}$ wide), solid, pruinose all over, longitudinally striate; reddish brown (27/S, 50/P, 49/R), brown, dark brown $(51 / \mathrm{T})$, yellow-brown, vinaceousbrown, apex sometimes paler, base white. Context in 


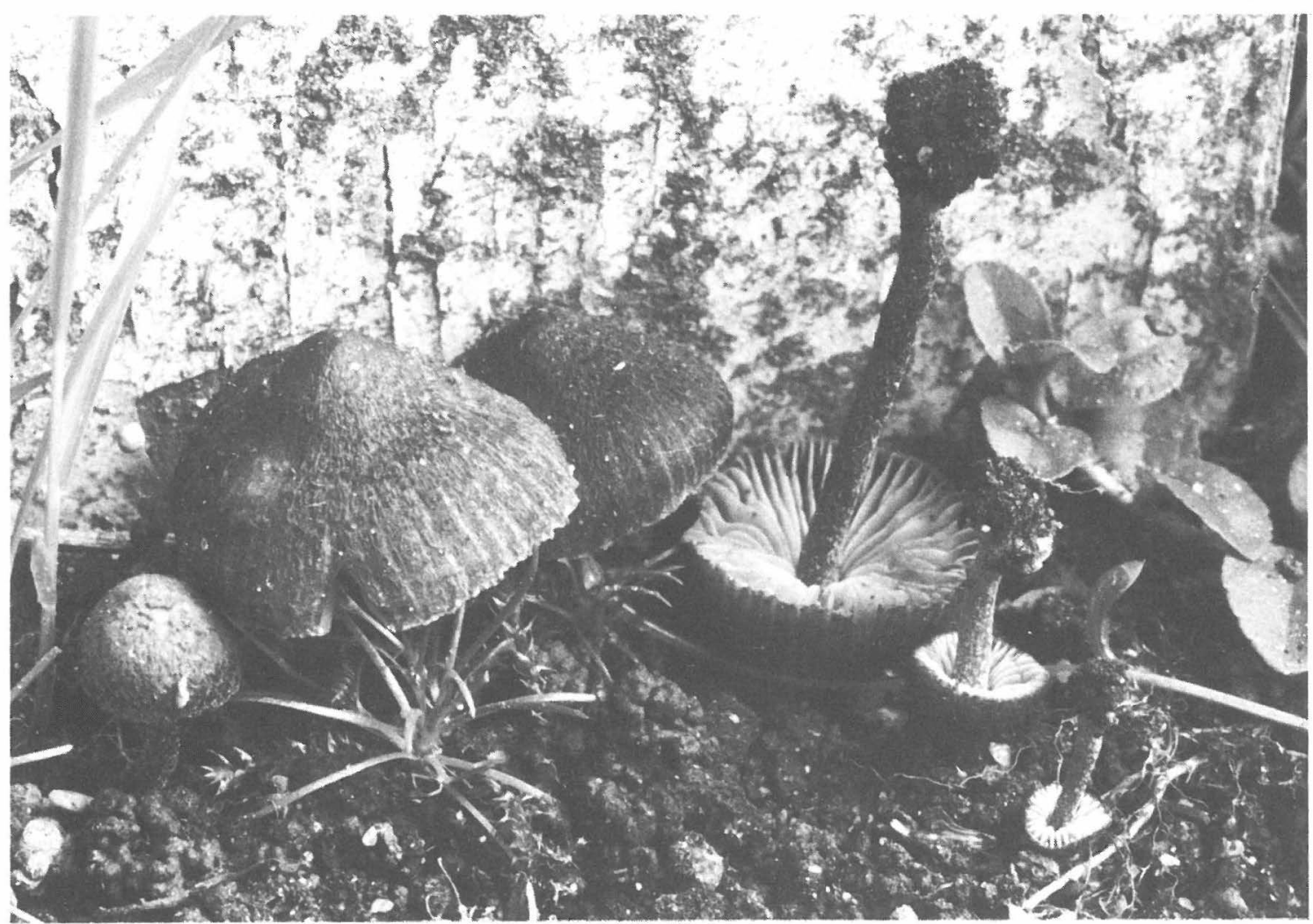

Fig. 1. Inocybe calospora, $\times 2$ (Vauras 1349F).

pileus whitish, pale yellow-brown to brown, in stipe yellow-brown to brown. Smell indistinct.

Spores (including the spines) $(10-) 11-14(-17) \times$ (8.5-)9.5-12.5(-14) $\mu \mathrm{m}$, range of mean values 11.7-13.7 $\times$ 9.1-11.8 $\mu \mathrm{m}$, the average measurements for 22 collections being $12.8 \times 10.9 \mu \mathrm{m}, \mathrm{Q}=$ (1.0-)1.1-1.3(-1.4), $\overline{\mathrm{Q}}=1.1-1.3$, the average for 22 collections being 1.18 , broadly ellipsoid to subglobose, spines 1.5-4 $\mu \mathrm{m}$ long, blunt. Basidia 30 $45 \times 9-14 \mu \mathrm{m}$, clavate to somewhat ventricose, 4spored. Pleurocystidia (27-)37-55(-62) $\times(8-) 10-15$ $(-18) \mu \mathrm{m}$, fusoid to clavate, typically with a long, cylindrical or downward-tapering pedicel, wall mostly yellowish, up to $3(-4) \mu \mathrm{m}$ thick; fairly frequent. Cheilocystidia similar to pleurocystidia, but mostly without pedicel, frequent. Paracystidia 13-25 × 7$12 \mu \mathrm{m}$, pyriform to clavate, thin-walled, colourless, fairly frequent. Caulocystidia occurring down to base of stipe, although scarce on lower third, rather irregular, up to $70 \mu \mathrm{m}$ long, mixed with numerous cauloparacystidia. Cuticle composed of hyphae 4 $21 \mu \mathrm{m}$ in diam, with brown, incrusted walls.
In Fennoscandia slightly calciphilous, mostly on lawns and in forests on roadsides or by paths, with at least Betula and Quercus. Rather rare from Temperate to Southern Boreal zone, and very rare up to Oroarctic zone. June to October.

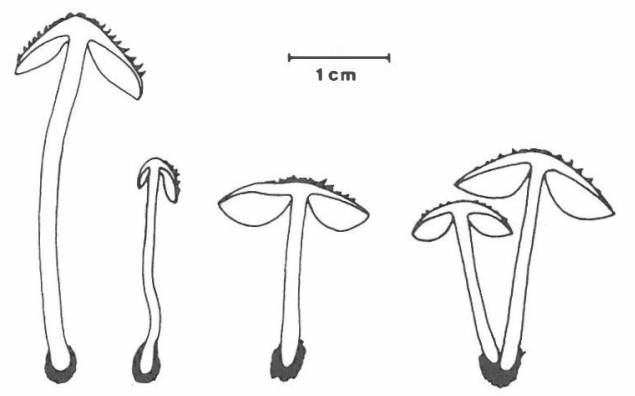

Fig. 2. Fruit bodies of Inocybe calospora, x 1 (Vauras 2661). 

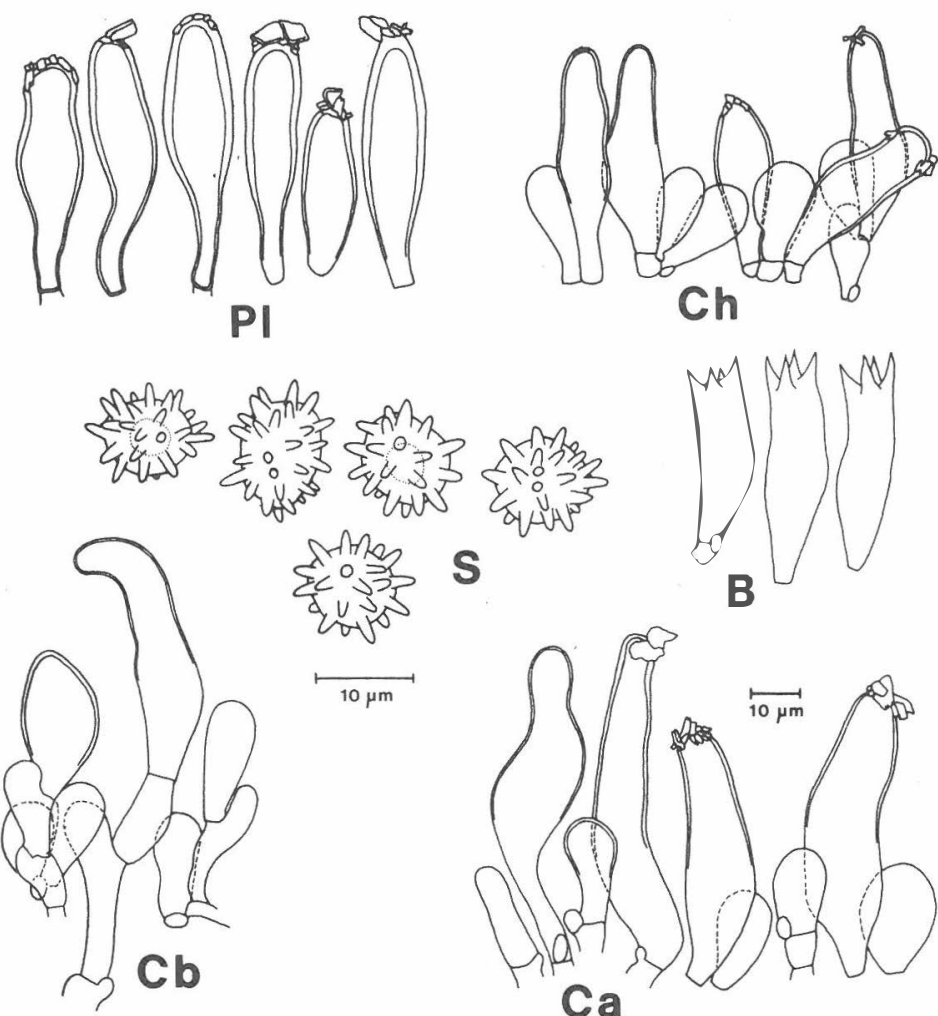

S

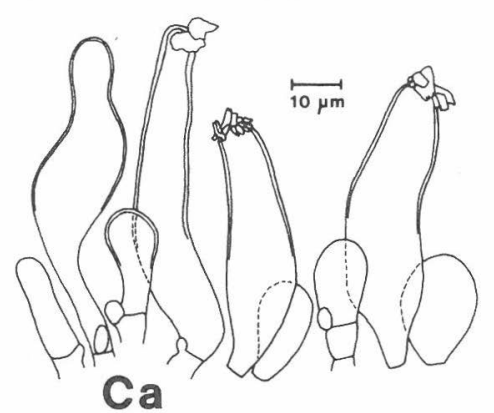

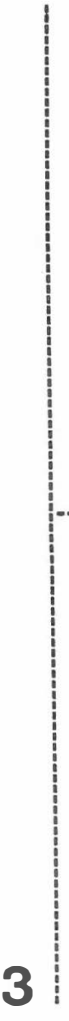
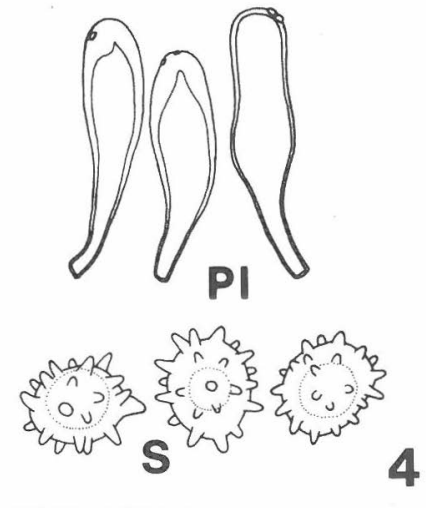

Figs. 3-5. Inocybe calospora. - 3: Vauras 1349F. - 4: A. Heino, H. Väre \& E. Ohenoja. - 5: Saarenoksa 9381. Scales: basidia and cystidia $\times 500$, spores $\times 1$ 000. (Symbols used in Figs. 3-5 and 8: $\mathrm{P}=$ pleurocystidia, $\mathrm{Ch}=$ cheilocystidia and paracystidia, $\mathrm{B}=$ basidia, $\mathrm{S}=$ spores, $\mathrm{Ca}=$ caulocystidia and paracystidia at apex of stipe, $\mathrm{Cm}=$ caulocystidia and paracystidia in middle of stipe, $\mathrm{Cb}$ = caulocystidia and paracystidia at base of stipe, $\mathrm{F}=$ fruit bodies.)

\section{Discussion}

Inocybe calospora is easily identified macroscopically, but can be confused with the very rare I. multicoronata or with I. leptophylla Atk. (I. casimiri Velen., I. lanuginosa (Bull. ex Fr.) Kummer var. casimiri (Velen.) R. Heim). The latter species has spores with only low knobs, and its stipe is not pruinose at all. Horak (1987) reported that the collection of I. calospora made by M. Lange in Greenland is Astrosporina casimiri (Velen.) Horak, but the microscopical characters of this tiny specimen do not match the drawings of the type specimen of $I$. casimiri by Kuyper (1985). So I agree with the original determination made by M. Lange. I prefer to synonymize I. gaillardii Gillet with I. calospora, as already done, e.g. by Heim (1931) and Alessio (1980). The illustrations of $I$. calospora by Rebaudengo (in Alessio 1980) accord with my field experience from Finland, but the colours in my material have been much darker. In the present study area the species is, however, easily recognized under the microscope. In the tropics of Indomalaya and Australasia the genus is represented by some other species with stellate spores (Horak 1979).

Alessio (1980) reported a wide range of variation in the macroscopical characters of I. calospora. Some variation may be found in the collections in the microscopical characters as well (size and shape of spores and cystidia, length of spines of spores, thickness of cystidial wall, and frequency of apical crystals on cystidia; Figs. 3-5). As these characters show considerable overlapping, the collections studied are treated as conspecific. The northemmost specimens, however, seem to have shorter spines on the spores.

I. calospora is known to have a wide distribution in the northem hemisphere. Besides occurring in Europe, it is reported to grow in India, the Himalayas (Horak 1981), Japan (Kobayasi 1952), the United 


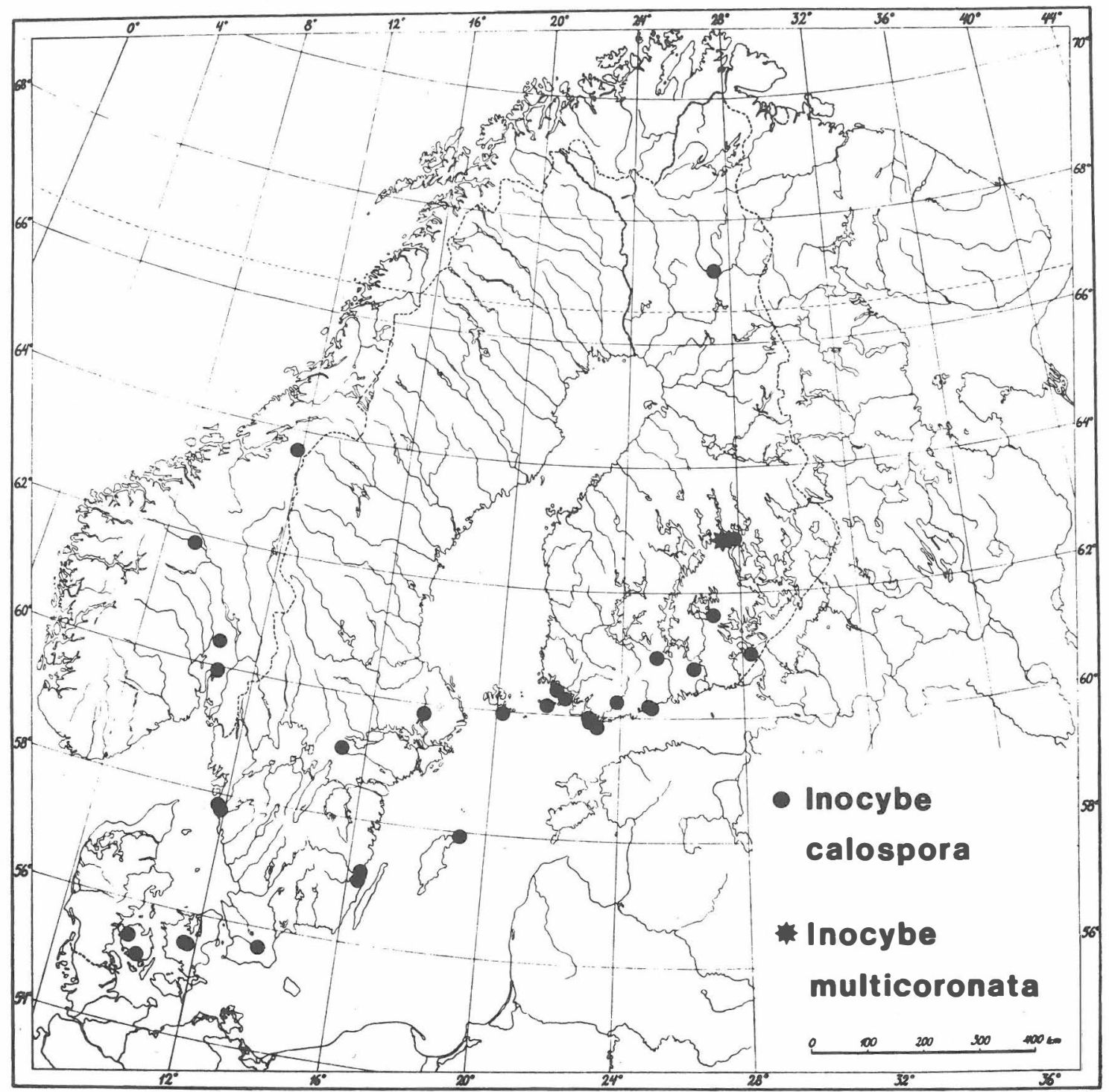

Fig. 6. Distribution of Inocybe calospora and I. multicoronata in NW Europe according to the material examined.

States (Kauffman 1924), Canada (Grund \& Stuntz 1980) and Greenland (Lange 1957).

In the study area I. calospora can be regarded as a rather rare species (Fig. 6), as also reported for Italy (Alessio 1980), the Netherlands (Amolds 1984) and East Germany (Kreisel 1987). In Estonia it has been collected in three localities (Leisner \& Kalamees 1987). In NW Europe most collection sites lie in the Temperate and Hemiboreal zones. In Finland $I$. calospora also has rare occurrences in the Southern Boreal zone and has been recorded once in the Northern
Boreal zone. In at least one case it has been found on a mountain above the timberline, in Norway (Gulden \& Lange 1971).

In Fennoscandia I. calospora has mostly been found growing on old lawns, and on roadsides or by paths in forests. When growing in parks, the species clearly favours bare ground, but fruits among grasses and mosses, as well. In the Nordic material studied, it has been collected only once beside a brook (Norway, Nord-Tröndelag), whereas in Central Europe the species is often reported to grow under.Alnus in 


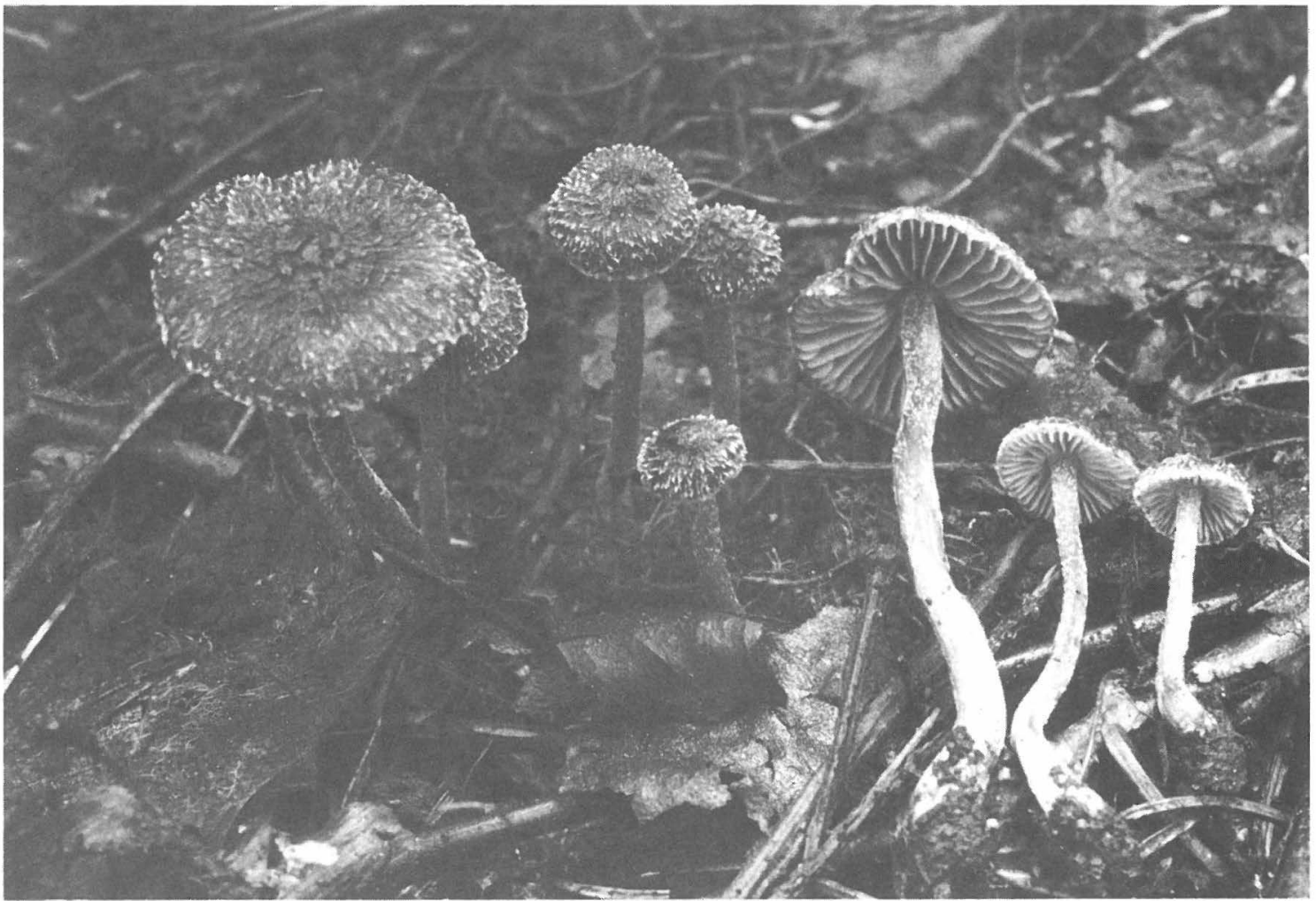

Fig. 7. Inocybe multicoronata, $\times 2$ (Vauras 2140F).

swampy and springy sites (e.g. Kreisel 1987, Stangl et al. 1987). I. calospora seems to prefer somewhat nutrient-rich, moist, calcareous soils. Some collections have, however, been made in rather dry sites. According to the information on labels, the collection sites have mostly had mould with a fine sand fraction, but occasionally muddy peaty mould or clay (ground cultivated previously). On my many visits to the surroundings of Finnish limestone-processing factories (with emissions of chalk dust) I have never found I. calospora in these areas. In Fennoscandia the species is mostly found under deciduous rees. It grows with Betula and Quercus, possibly also with Pinus, Corylus, Tilia and Salix.

In Fennoscandia $I$. calospora has a long fruiting season, beginning in late June, reaching a peak in late July-early September, and ceasing in mid-October (Fig. 9). The only specimen collected in the study area in June comes from Helsinki, Southern Finland. In Finland the fruiting period lasts to early September. All collections dating from late September to late October were made in SW Sweden, Gothenburg, in 1945. I. calospora seems to fruit irregularly, often being absent for many years without any clear climatic reasons, or the species is ephemeral. For example in 1981 I found an abundant occurrence in Kuopio, Central Finland, on a lawn in a park. In the following six years the site was visited regularly, but no fruit bodies were found.

\section{Specimens examined:}

Finland. Ahvenanmaa: Lemland, 1946 G. Stenlid (UPS). Varsinais-Suomi: Korppoo, 1941 O. Eklund (H). Lohja rural commune, $1965 \mathrm{H}$. Harmaja (H). Parainen, 1979 J. Vauras 419F (KUO, OULU, TUR), $1981 \mathrm{~J}$. Vauras 1042F (TUR). Rymättylä, 1979, 1981 R. Tuomikoski (H). Tenhola, 1938 N. Malmström (H), 1953 R. Tuomikoski (H), 1957 O. von Schulmann (H). Uusimaa: Elimäki, 1960 O. von Schulmann (H). Helsinki, 1979 R. Saarenoksa 35779 (H), 1981 R. Saarenoksa 9381, 33581, $38481(\mathrm{H}), 1982$ R. Saarenoksa 9882, 24682 (H), 1984 R. Saarenoksa 59684 (OULU), 1987 R. Saarenoksa 22087 (TUR). Tammisaari, 1938 N. Malmström (H). Etelä-Häme: Lammi, 1981, 1985 H. Harmaja (H). Etelä-Savo: Lappeenranta, 1984 J. Vauras 1656 (TUR). Mikkeli rural commune, 1987 J. Vauras 2661 (TUR). Pohjois-Savo: Kuopio, 1981 J. Vauras 987 (KUO), 1982 J. Vauras 1343 (KUO), 1349F (TUR), 1984 J. Vauras 1650, 1651 (TUR). Sompion Lappi: Pelkosenniemi, 1985 A. Heino, H. Väre \& E. Ohenoja (OULU). 

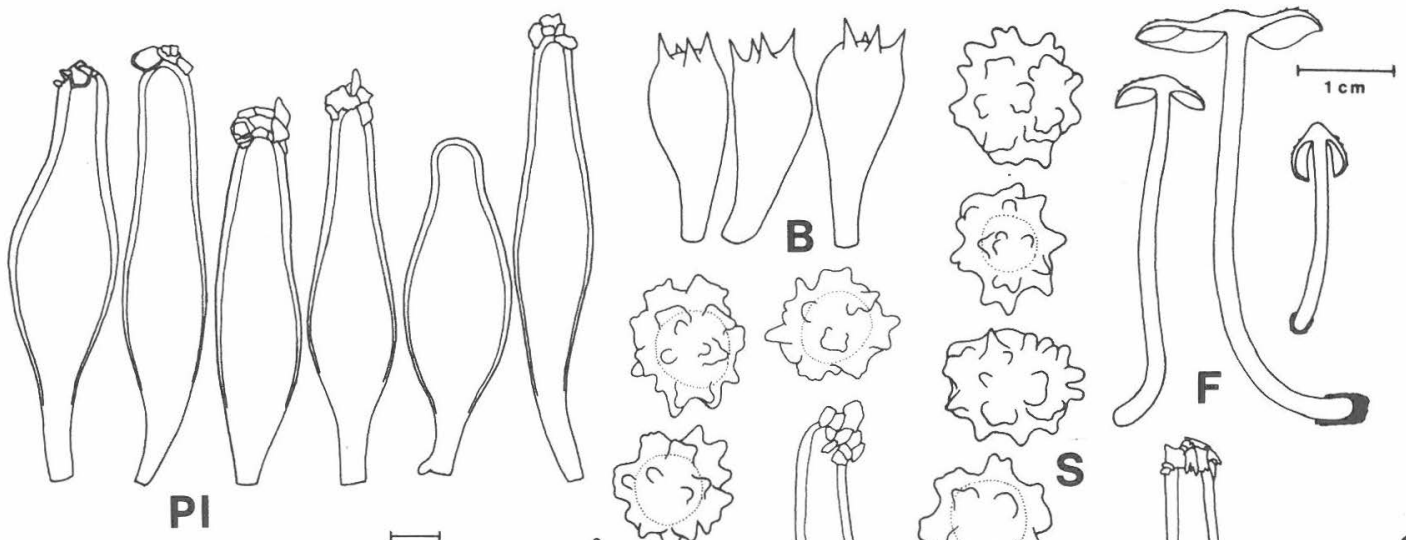

PI

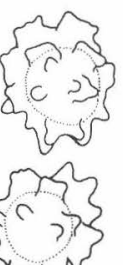

$\left\{\begin{array}{cc}3 \\ 6\end{array}\right.$
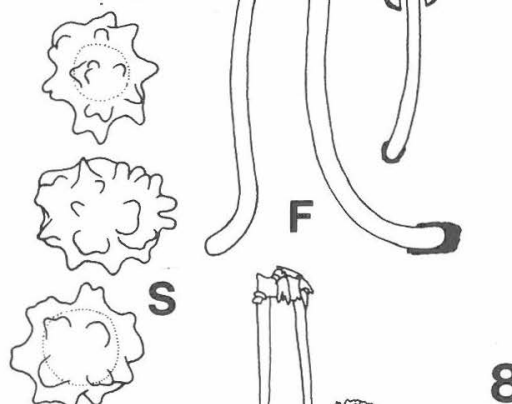

8
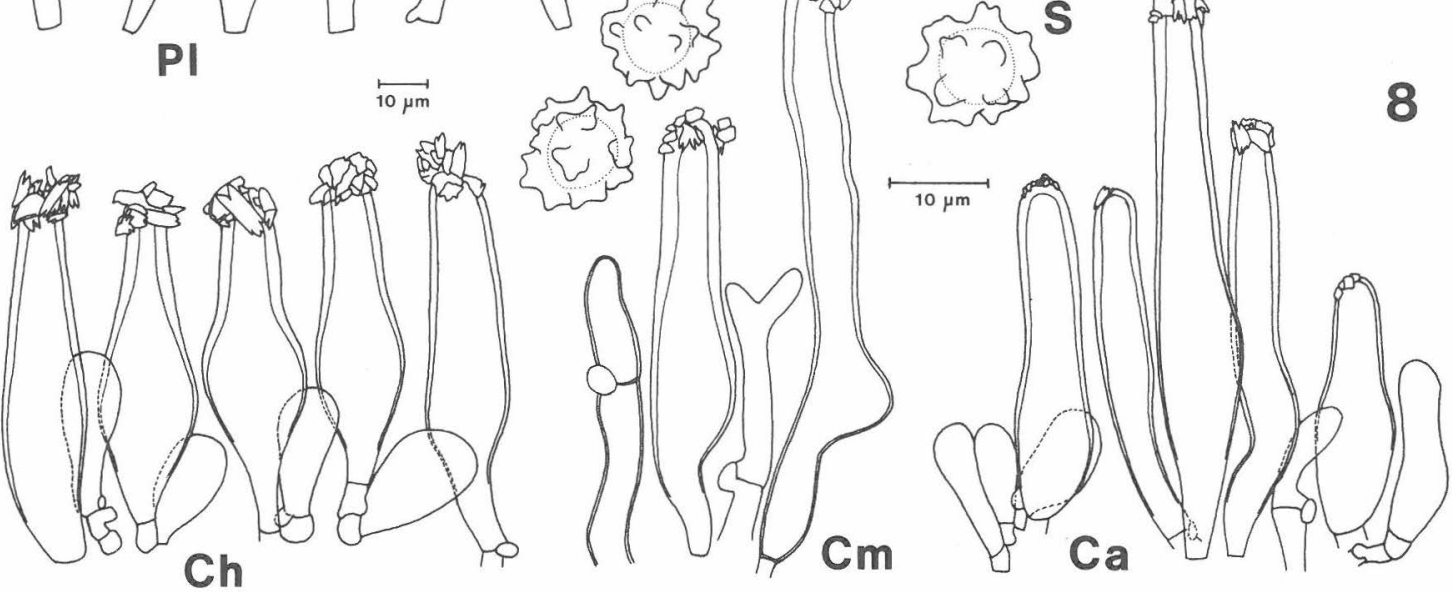

Fig. 8. Inocybe multicoronata (Vauras 2140F). For scales and symbols see Figs. 2-5.

Denmark. Fyn: Håre Bjerge, 1968 Mycological congress (C). Diemaes, 1970 E. Ohenoja (OULU). Sjaelland: Sorö Sö, 1970 Mycology course (2 ex. C). Locality not indicated, 1961 L. Dössing (C).

Norway. Akershus: Oslo, 1979 K. Høiland (O). Oppland: Lunner, 1979 T.E. Brandrud 42/79 (O). Vågå, 1969 M. Lange \& G. Gulden 500/69 (O). Nord-Tröndelag: Levanger, 1973 S. Sivertsen (THR).

Sweden. Skåne: Öved, 1952 O. Andersson (LD). Västergötland: Göteborg, 1945 F. Karlvall 2266, 2389, 2465 (GB; 2 ex. UPS), 1945 G. Soot (O), 1946 T. Nathorst-Windahl (GB), 1957 S.O. Andersson (GB), 1957 T. Nathorst-Windahl (GB). Småland: Fliseryd, 1954 O. Andersson (LD). Långemåla, 1952 O. Andersson (LD). Gotland: Fårö, 1947 E.Th. Fries (UPS). Närke: Kumla, 1885 L. Romell (S). Uppland: Uppsala, 1958 H. Belin (UPS).

Italy. Alto Adige: Trento, 1904 G. Bresadola (S). Florenz: Vallombrosa, 1980 Cetto (IB; M. Moser 80/104).

Poland. Biesczciade. Wetlina, 1975 M. Moser 75/295 (IB).

Greenland. West-Greenland: Nakajanga, 1946 M. Lange 267 (C).

United States. New York, Selkirk, Aug. (year not indicated) H. Peck (holotype of $I$. subfulva, NYS), Cayuga Lake Basin, 1902 Bradfield (S).
Inocybe multicoronata A.H. Smith

— Figs. 7, 8

Inocybe multicoronata A.H. Smith, Pap. Mich. Acad. Sci., Ars, and Lett. 24:95. 1939.

Pileus $0.5-2 \mathrm{~cm}$ in diam, $3-6 \mathrm{~mm}$ high, hemispherical or conico-convex when young, then expanding, obtusely umbonate; surface mostly fibrillose-squamulose, sometimes fibrillose-subtomentose, margin often grooved and whitish due to remnants of

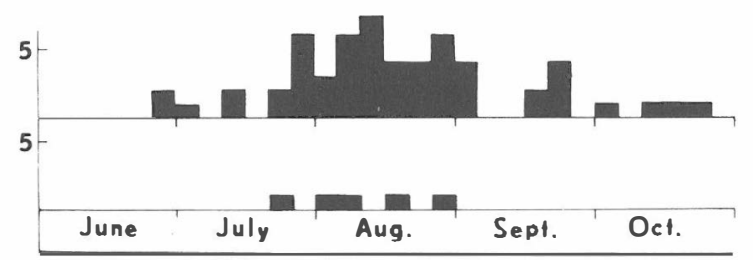

Fig. 9. Fruiting periods of Inocybe calospora (above) and $I$. multicoronata (below) according to all specimens examined, divided into pentads. 
cortina, which is present in very young specimens; dark brown $(33 / \mathrm{T}, 33 / \mathrm{S})$, but squamules whitish. Lamellae up to $3 \mathrm{~mm}$ broad, slightly adnexed, pale brown when young, then brown $(49 / \mathrm{N}, 49 / \mathrm{P})$; edge fimbriate, pale. Stipe $1.8-5.5 \mathrm{~cm}$ long, $1-2 \mathrm{~mm}$ wide, equal to somewhat clavate, solid; pruinose on more than upper half, white-fibrillose on lower third, weakly longitudinally striate, shiny; reddish brown $(25 / \mathrm{R}, 35 / \mathrm{R}, 35 / \mathrm{T})$, paler to sometimes nearly white at base. Context in pileus pale brown to brown, darkest under surface, in stipe pale to dark reddish, whitish in apex, darkest under cortex of stipe. Smell indistinct.

Spores (including the warts) $12-14 \times 10-12$ $(-13) \mu \mathrm{m}$, average $13.0 \times 11.1 \mu \mathrm{m}, \mathrm{Q}=1.1-1.2$ $(-1.4), \bar{Q}=1.2$, subglobose to ellipsoid, with multicoronate warts. Basidia 29-46 x 15-21 $\mu \mathrm{m}$, clavate, 4-spored. Pleurocystidia (50-)70-90(-105) x 14-23 (-26) $\mu \mathrm{m}$, subventricose to ventricose, rarely subcapitate, with up to $3 \mu \mathrm{m}$ thick, colourless to slightly yellowish wall, fairly frequent. Cheilocystidia similar to pleurocystidia, frequent. Paracystidia 21-33 x 11$18 \mu \mathrm{m}$, broadly clavate to pyriform, thin-walled, colourless, frequent. Caulocystidia occurring to over half-way down stipe, mostly subcylindrical, up to $120 \mu \mathrm{m}$ long, mixed with sparse cauloparacystidia. Cuticle composed of hyphae 5-23 $\mu \mathrm{m}$ in diam, with brown, incrusted walls.

In Fennoscandia very rare, twice recorded under deciduous and coniferous trees along a spring brook. Southem Boreal zone. August.

\section{Discussion}

The Finnish collection fits well with the macroscopical description by Smith (1939), and the detailed microscopical diagnosis of Grund \& Stuntz (1968). The dimensions of the spores and pleurocystidia also agree with those in the holotype collection of $I$. multicoronata, which measured (my measurements): spores (11.5-)12-13.5(-14) $\times 10-11.5(-13) \mu \mathrm{m}$, average $12.7 \times 10.8 \mu \mathrm{m}, \mathrm{Q}=1.1-1.2(-1.3), \bar{Q}=$ 1.2; pleurocystidia $67-95 \times 13-23 \mu \mathrm{m}$.

I. multicoronata is easily recognized under the microscope, and also differs macroscopically from $I$. calospora. The scales on the pileus are whitish, the stipe is white-fibrillose and lacks pruina on the lower third, and a cortina is present in juvenile fruit bodies. The dried Finnish specimens have a shiny pileus, though this character was not typical of the American specimens deposited in $\mathrm{MICH}$. In my experience, $I$. calospora is always matt when dried. Differences may exist in the ecology, too. I. calospora grows mostly in habitats influenced by man, e.g. in parks or on roadsides, whereas I. multicoronata grows in a fairly natural site in Finland. The type of the species was collected beside a brook (according to the label), like the Finnish specimen. On the other hand, like many members of the genus, both species favour bare ground.

The spores of I. multicoronata are rather unusual for the genus. Only some tropical species of Inocybe have somewhat similar spores: $I$. hyperythra Rick (Singer 1953), I. petchii Boed. (Boedijn 1951), I. lasseri Dennis (Dennis 1953, Pegler \& Young 1972, Pegler 1983), Astrosporina lasseroides Horak and $A$. alienospora Comer \& Horak (Horak 1979). Among these, only I. petchii has a totally pruinose stipe.

I. multicoronata was found twice in Central Finland, Kuopio, Neulaniemi, Grid $27^{\circ}$ E: 69770:5296, alt. $100 \mathrm{~m}$, in early August, in an old, shady herbrich forest on alluvial soil, by a small spring brook, near to Picea abies, Betula pendula, Alnus glutinosa, Populus tremula, Prunus padus, Daphne mezereum, Circaea alpina, Crepis paludosa, Filipendula ulmaria and Oxalis acetosella. The fungi growing in the vicinity were Inocybe nitidiuscula (Britz.) Sacc., Lactarius deterrimus Gröger and Russula lundellii Sing. In the cool and rainy summer of 1987 the site was flooded even in August, and no specimen of I. multicoronata was seen. The locality lies in the northem part of the Southern Boreal zone.

The collection sites of I. multicoronata in Canada, Nova Scotia, are located near to Fundy Bay, where it was reported to grow under spruce (Smith 1939, Grund \& Stuntz 1968). Nova Scotia lies within the boreo-nemoral transition zone (Pielou 1979), and the climatic conditions at the collection sites may not be very different from those in Central Finland, though the climate is more oceanic. In the United States (New York), the species has been collected by A.H. Smith, but, as far as I know, the collection has not been reported. According to the material examined the species fruits from late July to late August (Fig. 9).

\section{Specimens examined:}

Finland. Pohjois-Savo: Kuopio, 1986 J. Vauras 2140F (H, KUO, M, OULU, TUR), 1988 J. Vauras 3112 (TUR).

Canada. Nova Scotia: Colchester, 1931 A.H. Smith (holotype, paratype; MICH).

United States. New York, 1934 A.H. Smith 353 (MICH).

Acknowledgements. My thanks are due to the curators of the herbaria which kindly sent material on loan. Valuable advice was received from the following persons: Mr Johan Nitare (Uppsala), Mr Poul Printz (Copenhagen), Mr Reima Saarenoksa (Helsinki), Prof. Rolf Singer (Chicago), and Mr Johann Stangl (Augsburg). My thanks are also due to Dr Harri Harmaja (Helsinki), Mr Seppo Huhtinen, Lic.Phil. (Turku), and Mr Tauno Ulvinen, Lic.Phil. (Oulu), for their comments on the manuscript. The study was supported by grants from the Emil Aaltonen foundation and Suomen Kulttuurirahasto. 


\section{References}

Alessio, C.L. 1980: Inocybe. - Iconographia Mycologica Ab. Dr. J. Bresadola 29, Suppl. 3. 367 pp., 100 pls. Trento.

Arnolds, E. 1984: Standaardlijst van Nederlandse Macrofungi. - Coolia 26 (Suppl.): 1-362.

Boedijn, K.B. 1951: Some mycological notes. - Sydowia 5:211-229.

Cailleux, A.[the year not indicated]: Code des couleurs des sols. - Boubée.

Dennis, R.W.G. 1953: Les Agaricales de l'Ile de la Trinité: Rhodosporae - Ochrosporae. - Bull. Soc. Mycol. France 69:145-198.

Grund, D.W. \& Stuntz, D.E. 1968: Nova Scotian Inocybes. I. - Mycologia 60:406-425.

- 1980: Nova Scotian Inocybes. V. - Mycologia 72:670 688.

Gulden, G. \& Lange, M. 1971: Studies in the macromycete flora of Jotunheimen, the central mountain massif of South Norway. - Norw. J. Bot. 18:1-46.

Horak, E. 1979: Astrosporina (Agaricales) in Indomalaya and Australasia. - Persoonia 10:157-205.

- 1981: On Himalayan species of Astrosporina and Inocybe (Agaricales). - Persoonia 11:303-310.

- 1987: Astrosporina in the alpine zone of the Swiss National Park (SNP) and adjacent regions - In: Laursen, G.A., Ammirati, J.F. \& Redhead, S.A. (eds.), Arctic and Alpine Mycology 2:205-234.

Kauffman, C.H. 1924: Inocybe. - North Amer. Flora 10:
227-260.

Kobayasi, Y. 1952: On the genus Inocybe from Japan. Nagaoa 2:76-115.

Kreisel, H. 1987: Pilzflora der Deutschen Demolratischen Republik. -281 pp. Jena.

Kuyper, Th.W. 1985: Studies in Inocybe - I. Revision of the new taxa of Inocybe described by Velenovsky. Persoonia 12:375-400.

Lange, M. 1957: Macromycetes III. Greenland Agaricales. Medd. Grönl. 148:1-125.

Leisner, T. \& Kalamees, K. 1987: Eesti narmasnutid. 144 pp. Tallinn.

Pegler, D.N. 1983: Agaric flora of the Lesser Antilles. Kew Bull. Add. Ser. 9:1-668.

Pegler, D.N. \& Young, T.W.K. 1972: Basidiospore form in the British species of Inocybe. - Kew Bull. 26: 499-537.

Pielou, E.C. 1979: Biogeography. - 351 pp. New York.

Singer, R. 1953: Type studies on Basidiomycetes VI. Lilloa 26:57-159.

Smith, A.H. 1939: Certain species of Inocybe in the Herbarium of the University of Michigan. - Pap. Mich. Acad. Sci., Arts, and Lett. 24:93-106.

Stangl, J., Sedlmeir, A. \& Geh, G. 1987: Beobachtungen über das Pilzwachstum in den Flussauen der Wertach südlich von Augsburg. - Beih. Zeitschr. Mykol. 7: 167-218.

Received on 3 June 1988 